\title{
Article \\ Study of the Incorporation of Biomass Bottom Ash as a Filler for Discontinuous Grading Bituminous Mixtures with Bitumen Emulsion
}

\author{
Jorge Suárez-Macías *, Juan María Terrones-Saeta (D), Francisco Javier Iglesias-Godino (D) \\ and Francisco Antonio Corpas-Iglesias
}

check for

updates

Citation: Suárez-Macías, J.;

Terrones-Saeta, J.M.; Iglesias-Godino,

F.J.; Corpas-Iglesias, F.A. Study of the Incorporation of Biomass Bottom Ash

as a Filler for Discontinuous Grading Bituminous Mixtures with Bitumen Emulsion. Appl. Sci. 2021, 11, 3334. https://doi.org/10.3390/ app11083334

Academic Editor:

Francesco Colangelo

Received: 15 March 2021

Accepted: 6 April 2021

Published: 8 April 2021

Publisher's Note: MDPI stays neutral with regard to jurisdictional claims in published maps and institutional affiliations.

Copyright: (c) 2021 by the authors. Licensee MDPI, Basel, Switzerland. This article is an open access article distributed under the terms and conditions of the Creative Commons Attribution (CC BY) license (https:// creativecommons.org/licenses/by/ $4.0 /)$.
Department of Chemical, Environmental and Materials Engineering, Higher Polytechnic School of Linares, Scientific and Technological Campus of Linares, University of Jaen, 23700 Jaen, Spain; terrones@ujaen.es (J.M.T.-S.); figodino@ujaen.es (F.J.I.-G.); facorpas@ujaen.es (F.A.C.-I.)

* Correspondence: jsuarez@ujaen.es

\begin{abstract}
Energy consumption, because of population development, is progressively increasing. For this reason, new sources of energy are being developed, such as that produced from the combustion of biomass. However, this type of renewable energy has one main disadvantage, the production of waste. Biomass bottom ash is a residue of this industry that currently has not much use. For this reason, this research evaluates its use as a filler in bituminous mixtures, since this sector also has a significant impact on the environment, as it requires large quantities of raw materials. With this objective, first, the physical and chemical properties of biomass bottom ashes were evaluated, verifying their characteristics for their use as filler. Subsequently, bituminous mixtures were conformed with biomass bottom ash as filler, and their physical and mechanical properties were analyzed through particle loss and Marshall tests. The results of these tests were compared with those obtained with the same type of mixture but with conventional and ophite aggregates. This study confirmed that biomass bottom ash was viable for use as a filler, creating mixtures with a higher percentage of bitumen, better mechanical behavior, and similar physical properties. In short, more sustainable material for roads was obtained with waste currently condemned to landfill.
\end{abstract}

Keywords: biomass bottom ash; energy production; waste-to-energy; discontinuous grading; bitumen emulsion; bituminous mixture; filler; circular economy; sustainable construction

\section{Introduction}

The development of industry has succeeded in improving the welfare of the population. However, this development has also created a negative environmental impact. Mainly energy generation, for all industrial sectors, is an activity that has a significant impact on the environment. Therefore, new forms of renewable energy production are being developed [1].

Among the new renewable energy sources, such as wind and solar, biomass combustion is one of the most promising [2]. So much so that the European community has increased the production of thermal and electrical energy from biomass in recent years. More specifically, Andalucía is the Spanish leader in biomass energy production, with 18 plants and more than 257.48 MW of energy generation [3,4]. However, this type of energy source has some environmental disadvantages that must be overcome, mainly the generation of waste [5]. In Spain alone, 120,000 tons of waste are produced annually from biomass combustion [6], with biomass fly ash and biomass bottom ash being the main by-products produced, 64 and 36\%, respectively [7].

Biomass fly ash has been analyzed by different researchers in order to find new utilization pathways [8]. The main research carried out is based on the use of biomass fly ash as a partial substitute for cement [8], as an additive in concrete [9], for the manufacture 
of geopolymers [10], as an element for soil improvement for agriculture (thanks to its chemical composition) [11], and even for nanotechnology [12]. In most cases, the results obtained were acceptable, and the reuse of a waste condemned to landfill was achieved.

On the other hand, biomass bottom ash has been investigated to a lesser extent and is currently an unused waste. Some of the little research that has been carried out has been based on the incorporation of biomass bottom ash for the manufacture of new materials. Biomass bottom ash has been used, at the research level, as a partial substitute for cement, as a concrete additive, and for stabilization of expansive soils in road construction [13]. The results of these investigations showed a decrease in the density of the final product, due to the reduced density of the ashes, as well as adequate mechanical properties, due to the increase in pozzolanic activity as a result of their use [14].

At the same time, the construction sector is currently one of the most polluting sectors, especially in road construction [15]. This is mainly due to the fact that this activity uses enormous quantities of raw materials, develops production processes with high temperatures that are not optimized, and as a consequence, produces considerable greenhouse gas emissions [16]. In order to solve this environmental problem, several research projects have been carried out to modify production processes and use waste as raw materials for this sector [17].

Research into the improvement of production processes is mainly based on the use of new techniques to reduce the temperature at which bituminous mixes are formed, as these are the main element in the production of high-quality, comfortable, and safe roads [18]. Temperature reduction techniques are mainly based on the use of bitumen emulsions [19], as the mixes are formed with this binder at ambient temperature, thus avoiding the heating of the bituminous mix at high temperatures by fossil fuels [20]. At the same time, and with the aim of reducing the extraction of raw materials, waste has been reused for the formation of bituminous mixtures. These wastes include scrap tires [21], mining waste [22,23], ceramic waste [24], recycled concrete aggregate [25], steel slags [26-28], recycled glass [29], etc. Most of the investigations concluded that a detailed study of the physical, chemical, and mechanical properties of the wastes, as well as a thorough knowledge of the bituminous mixes, led to end products of similar quality to those made with conventional materials and techniques.

Based on the above, in this research new bituminous mixtures of discontinuous grading with bitumen emulsion and biomass bottom ash as filler are developed. The biomass bottom ash comes from the combustion of almond shells and alpeorujo. In this way, on the one hand, the production process is environmentally optimized by reducing the conformation temperature; on the other hand, the use of a waste product, such as biomass bottom ash, avoids the landfilling of this by-product and avoids the extraction of new raw materials. As a result, the environmental impacts caused by the preparation of bituminous mixtures are quantitatively reduced. Moreover, the conformation of discontinuous grading bituminous mixtures with biomass bottom ash and bitumen emulsion produces bituminous mixtures that are more economical (by reducing the percentage of raw materials), more sustainable (by using a high percentage of waste), and safer for drivers (by having a high void content), capable of providing a high macro texture that increases the friction between the tire and the pavement.

In order to carry out this research, first of all, the biomass bottom ashes were analyzed chemically and physically, evaluating the critical points they had as well as the particularities that should be taken into account. Subsequently, different bituminous mixtures were formed with coarse and fine ophite aggregate, biomass bottom ash, and increasing percentages of binder, bitumen emulsion. Finally, the physical and mechanical properties of the discontinuous grading bituminous mixtures formed with biomass bottom ash were evaluated, comparing the results with the same type of mixture formed with limestone filler and ophite filler. The results of the three types of mixtures were analyzed, evaluating the advantages produced by the use of biomass bottom ashes as filler in bituminous mixtures with bitumen emulsion and discontinuous grading. 
The results showed that the use of biomass bottom ash for the conformation of this type of bituminous mixture produced an increase in the mechanical strength of the mixture compared to the use of other fillers such as limestone or bitumen, maintaining similar physical properties and absorbing a higher percentage of bitumen. In short, it was possible to prove that the use of biomass bottom ash as a filler in discontinuous grading bituminous mixtures with bitumen emulsion developed sustainable materials, with better mechanical properties, with similar physical properties and without the extraction of new raw materials.

\section{Materials and Methods}

This section describes the materials used, whether waste or commercial materials, as well as the tests carried out to characterize the biomass bottom ash and the different bituminous mixtures.

\subsection{Materials}

The materials used in this research are mainly biomass bottom ash, limestone filler, ophite filler, ophite aggregate (coarse and fine), and bitumen emulsion. Biomass bottom ash is the waste that is evaluated in this research. Therefore, first, its origin and general characteristics are described. Subsequently, and through different tests, it is analyzed physically and chemically in depth. The rest of the materials is commercial, so this section describes their origin as well as their general characteristics.

It should be noted that the biomass bottom ash, the limestone filler and the ophite material were dried at a temperature of $105 \pm 2{ }^{\circ} \mathrm{C}$ for $24 \mathrm{~h}$. In this way, it was possible to eliminate the humidity in them in order not to induce more variables that could disturb the final results. Nevertheless, the existence of humidity in the commented materials and during the industrial process would not be detrimental to the final material, it should simply be taken into account in order to obtain a quality final product.

In turn, it must be mentioned that the biomass bottom ashes were analyzed over time to corroborate that their physical and chemical properties remained unaltered. This fact is essential for the reuse, since if this were not the case, the continuous variability of the properties would lead to the continuous reformulation of the elements of the final product, obtaining a process of higher economic cost and, in the worst case, a final product of low quality or variable quality.

\subsubsection{Biomass Bottom Ash}

Biomass bottom ash, or BBA, belongs to the biomass power generation industry, located in the region of Andalucía, Spain. These biomass bottom ashes come from the combustion of almond shells and alpeorujo.

The ashes have a continuous grading in which mainly small-sized particles are present. However, larger particles up to $8 \mathrm{~mm}$ are also present. Due to the biomass used, the crushing of the ashes to obtain a quality filler is simple, being a low-cost process due to the low mechanical resistance of the biomass bottom ash. Consequently, the biomass bottom ash was crushed and sieved through a $2 \mathrm{~mm}$ sieve, obtaining a reduced particle size, which is shown in the Results section.

\subsubsection{Limestone Filler}

The limestone filler used to compare the properties of bituminous mixtures made with biomass bottom ash comes from the region of Andalucía, Spain. This filler is usually used in bituminous mixtures, due to its small particle size as well as its excellent compatibility with the binder because of its chemical composition.

Limestone filler is derived directly from the crushing of calcareous rocks. Limestone is a sedimentary rock composed mainly of calcium carbonate $\left(\mathrm{CaCO}_{3}\right)$, generally calcite, although it frequently contains traces of magnesite $\left(\mathrm{MgCO}_{3}\right)$ and other carbonates. It may also contain small amounts of minerals such as clay, hematite, siderite, quartz, etc., which 
modify (sometimes noticeably) the color and degree of coherence of the rock. This type of rock is mainly used for construction materials.

The general properties of limestone filler are shown in Table 1.

Table 1. Physical properties of limestone filler.

\begin{tabular}{ccc}
\hline Test & Standard & Value/Unit \\
\hline Particle density & UNE-EN 1097-7 [30] & $2.62 \pm 0.07 \mathrm{t} / \mathrm{m}^{3}$ \\
Bulk density & UNE-EN 1097-3 [31] & $0.70 \pm 0.01 \mathrm{t} / \mathrm{m}^{3}$ \\
Plasticity index & UNE-EN ISO 17892-12 [32] & $4.1 \pm 0.1 \%$ \\
\hline
\end{tabular}

\subsubsection{Ophite Aggregate and Filler}

The ophite aggregate is the one used as coarse and fine aggregate in all the bituminous mixtures conformed in this research. This fact is due to its excellent mechanical strength and particle shape, so its use in bituminous mixtures of discontinuous grading is excellent, since the compressive loads are resisted mainly by the friction of the aggregates. In turn, this type of aggregate also produces an ophite filler, used in this research to compare the results of mixtures made with biomass bottom ash. The ophite aggregate and filler come from the region of Andalucía, Spain.

These materials come from the rock called ophite. Ophites are, from a geological point of view, rocks of a subvolcanic nature coming from magmas that did not fully reach the surface, solidifying at shallow depths. They have intermediate characteristics between plutonic and volcanic rocks, so they belong to a special petrographic group. They are usually found embedded mainly in sedimentary rocks, although they have also been found in metamorphic and igneous rocks. Ophites are mafic rocks, of basaltic composition and are composed mainly of silicate minerals called pyroxenes and plagioclase, with some potassium feldspar, olivine, quartz, or feldspathoids. The way its mineral components are arranged, that is to say, its texture is called ophitic and consists of presenting a framework of pyroxene crystals including disoriented tabular crystals of plagioclase.

The main properties of the ophite filler and aggregate are presented in Table 2.

Table 2. Physical and mechanical properties of ophite aggregate and fillers.

\begin{tabular}{ccc}
\hline & Ophite Filler & \\
\hline Test & Standard & Value/Unit \\
\hline Particle density & UNE-EN 1097-7 [30] & $2.71 \pm 0.07 \mathrm{t} / \mathrm{m}^{3}$ \\
Bulk density & UNE-EN 1097-3 [31] & $0.65 \pm 0.02 \mathrm{t} / \mathrm{m}^{3}$ \\
Plasticity index & UNE-EN ISO 17892-12 [32] & $2.2 \pm 0.1 \%$ \\
\hline & Ophite aggregate & \\
\hline Test & Standard & Value/Unit \\
\hline Resistance to fragmentation & UNE-EN 1097-2 [33] & $14 \pm 1 \%$ \\
Resistance to freezing and thawing & UNE-EN 1367-1 [34] & $0.865 \pm 0.022 \%$ \\
Polished stone value & UNE-EN 1097-8 [35] & $57 \pm 2$ \\
\hline
\end{tabular}

\subsubsection{Bitumen Emulsion}

The binder is one of the main elements in bituminous mixtures. In order to minimize the environmental effects of the conformation of bituminous mixtures, bitumen emulsion is used as a binder in this research. The use of this type of binder has a main advantage over others, which is that it is formed at room temperature, since it is not necessary to raise the temperature of the bituminous mixture to high temperatures to obtain the mixture.

The bitumen emulsion is mainly composed of water and bitumen. Both elements are immiscible, so it is necessary to carry out a process in which they are homogeneously mixed and an emulsifier is added to prevent the separation of the aforementioned elements. The nature of this emulsifier is essential, since it must react with the aggregate of the 
bituminous mixture producing the breaking of the emulsion. When the emulsion breaks, the bitumen envelops the aggregate, and the water is free to evaporate by natural processes. Therefore, the chemical nature of the emulsifier and the emulsion must be compatible with the aggregate for this process to occur. In this case, and due to the fact that the main element is the ophite aggregate, the emulsion selected is of a cationic nature. This type of emulsion reacts adequately with the composition of the ophite aggregate.

At the same time, the emulsion must have an adequate breaking time, otherwise the mixing and spreading times on the infrastructure would be unacceptable. Emulsions are classified according to their breaking time as fast, medium, and slow. This factor is mainly conditioned by the percentage of fine aggregate and filler. Specifically, and due to the fact that the bituminous mixture developed in this research has a discontinuous grading in which the percentage of fine aggregate and filler is reduced, an emulsion with medium breaking time was used. If, on the other hand, the percentage of fines is high, an emulsion with a slow breaking time should be used to allow an adequate mixing time for coating all the aggregates. In short, the emulsion chosen is a medium cationic emulsion, designated according to European standards as C60BF3 MBA. However, the compatibility of this emulsion with the aggregates will be studied in the methodology.

Table 3 shows the general characteristics of the C60BF3 MBA emulsion.

Table 3. Technical details of the bitumen emulsion C60BF3 MBA used.

\begin{tabular}{|c|c|c|c|c|}
\hline Characteristics & Unit & Standard & Min. & Max. \\
\hline \multicolumn{5}{|c|}{ Original Emulsion } \\
\hline Particle polarity & - & UNE EN 1430 [36] & Positive & \\
\hline Breaking value (Forshammer filler) & $\mathrm{g}$ & UNE EN 13075-1 [37] & 70 & 155 \\
\hline Binder content (per water content) & $\%$ & UNE EN 12846-1 [38] & 58 & 62 \\
\hline Oil distillate content & $\%$ & UNE EN 1431 [39] & - & 5 \\
\hline Efflux time $\left(2 \mathrm{~mm} ; 40^{\circ} \mathrm{C}\right)$ & $\mathrm{s}$ & UNE EN 12,846 [40] & 40 & 130 \\
\hline Residue on sieving (0.5 mm) & $\%$ & UNE EN 1429 [41] & - & 0.10 \\
\hline Setting tendency (7 days storage) & $\%$ & UNE EN 12,847 [42] & - & 5 \\
\hline Water effect of binder adhesion & $\%$ & UNE EN 13,614 [43] & 90 & - \\
\hline \multicolumn{5}{|c|}{ Binder after distillation (UNE EN 1431 [39]) } \\
\hline Penetration $\left(25^{\circ} \mathrm{C} ; 100 \mathrm{~g} ; 5 \mathrm{~s}\right)$ & $0.1 \mathrm{~mm}$ & UNE EN 1426 [44] & - & 220 \\
\hline Softening point & ${ }^{\circ} \mathrm{C}$ & UNE EN 1427 [45] & 35 & - \\
\hline \multicolumn{5}{|c|}{ Evaporation residue (UNE EN 13074-1 [46]) } \\
\hline Penetration $\left(25^{\circ} \mathrm{C} ; 100 \mathrm{~g} ; 5 \mathrm{~s}\right)$ & $0.1 \mathrm{~mm}$ & UNE EN 1426 [44] & - & 330 \\
\hline Softening point & ${ }^{\circ} \mathrm{C}$ & UNE EN 1427 [45] & 35 & - \\
\hline \multicolumn{5}{|c|}{ Stabilizing residue (UNE EN 13074-2 [47]) } \\
\hline Penetration $\left(25^{\circ} \mathrm{C} ; 100 \mathrm{~g} ; 5 \mathrm{~s}\right)$ & $0.1 \mathrm{~mm}$ & UNE EN 1426 [44] & - & 220 \\
\hline Softening point & ${ }^{\circ} \mathrm{C}$ & UNE EN 1427 [45] & 35 & - \\
\hline
\end{tabular}

\subsection{Methodology}

The methodology followed in this research is based on a series of logically ordered tests to evaluate the physical and chemical suitability of biomass bottom ash for use as a filler in bituminous mixtures. Subsequently, different types of discontinuous granulometry bituminous mixtures are made with bitumen emulsion and biomass bottom ash filler. Additionally, the same type of bituminous mixture is made with limestone filler and ophite filler, in order to compare the physical and mechanical properties of the mixtures obtained through different tests and to objectively analyze the improvements produced by the use of ashes. The methodology is described in detail in the following sections. 


\subsubsection{Characterization of Biomass Bottom Ash}

Firstly, it is essential to chemically and physically characterize the biomass bottom ash in order to analyze, on the one hand, the elements and chemical compounds present in it and, on the other hand, the physical properties that corroborate its suitability as a filler in bituminous mixtures. The biomass bottom ash samples for the subsequent tests were prepared as described in the materials section.

The first of the tests performed is the X-ray fluorescence test, because the biomass bottom ash comes from a combustion process, and it is assumed that the nature of the sample will be mainly inorganic. Therefore, the $\mathrm{X}$-ray fluorescence test was performed with the commercial ADVANT'XP+ (AD-VANT'XP+, Thermo Fisher, Waltham, MA, USA) to detect the presence of the higher atomic weight chemical elements.

It should be noted that the X-ray fluorescence test is an elemental analysis, i.e., it provides the chemical elements present in the sample as well as the proportion in which they are found. However, the chemical elements have greater or lesser activity depending on the chemical compound in which they are combined. Therefore, it is essential to determine the main chemical compounds present in the sample. These chemical compounds are determined in this research through the X-ray diffraction test. Powder X-ray diffraction is a very powerful technique capable of evaluating (identifying, quantifying, and studying) the crystalline phases present in any type of material, whether natural or synthetic, as well as determining the crystalline structure of solids. This test was carried out with the equipment model X'Pert PRO of the commercial brand PANalytical (X'Pert PRO, PANalytical, Malvern, UK).

In turn, the utilization of an industrial waste must avoid environmental pollution caused by its disposal in landfills. Therefore, in order to evaluate that this fact occurs, in this research, the biomass bottom ash leachate is analyzed according to the UNE-EN 12457-3 standard [48]. In this way, it is possible to confirm that the concentration of contaminating elements in the biomass bottom ash leachate are lower than the limits established by the regulations, and consequently, the use of this waste is viable for bituminous mixtures. For this purpose, the dry mass used was $0.175 \mathrm{~kg}$, and the following two steps were carried out. First, a quantity of lixiviant (deionized water) was added to obtain a ratio $\mathrm{L} / \mathrm{S}=2 \mathrm{~L} / \mathrm{kg}$, and then stirred for $6 \mathrm{~h}$ at a speed of between 5 and 10 revolutions/minute. Finally, the sample was filtered through a $0.45 \mu \mathrm{m}$ filter. Secondly, deionized water was added on top of the previous sample until a $\mathrm{L} / \mathrm{S}$ ratio $=10 \mathrm{~L} / \mathrm{kg}$ was achieved. The sample was then shaken for $18 \mathrm{~h}$ and finally filtered through $0.45 \mu \mathrm{m}$ filters. The sample obtained was analyzed for the determination of the concentrations of the pollutants. For the analysis of the leachate, the commercial equipment Agilent 7900 (7900, Agilent, Santa Clara, CA, USA) was used.

After analyzing the chemical composition of the biomass bottom ash and evaluating its chemical suitability for use as a filler in bituminous mixtures, the general physical properties of the ash were determined to corroborate its suitability.

The first of the grading tests was the determination of the grading curve, since the ashes will be used as filler in bituminous mixtures and must have a small particle size. This test, using the laser particle size test technique, can detect particles between 1 and $2000 \mathrm{mi}-$ crometers in size. The Mastersizer 2000LF (Mastersizer 2000LF, Malvern Instruments, Malvern, UK) was used for this test.

Subsequently, in order to obtain qualitative information on the surface of the particles, a scanning electron microscope test was performed on the biomass bottom ash. In this way, the surface of the ashes could be observed, and thanks to the high magnifications of this instrument, the presence of micropores that significantly influence the specific surface of the biomass bottom ashes could be detected. The scanning electron microscope used was a high resolution (FESEM) MERLIN (Carl Zeiss, Oberkochen, Germany) with EDX and WDX (Oxford Analytical, High Wycombe, UK) capabilities.

Finally, the main physical properties that make it possible to evaluate the suitability of a filler, as well as the special care that must be taken in its use, were determined by means 
of three tests. These tests are the particle density test, according to the UNE-EN 1097-7 standard [30], to evaluate whether the ash density is similar to that of a commercial filler; the kerosene bulk density, according to the UNE-EN 1097-3 [31] standard, to determine whether the residue is pulverulent; and finally, the plasticity index test, according to the UNE-EN ISO 17892-12 [32] standard, to determine whether the percentage of clayey particles is high and could cause subsequent expansivity problems.

\subsubsection{Conformation of Bituminous Mixtures and Tests}

Once the chemical and physical characteristics of the biomass bottom ash had been analyzed, the different bituminous mixtures were formed. First, the grading curve of the bituminous mixtures was established. This grading curve is composed of ophite aggregate (coarse and fine) and three different types of filler (limestone AOFC, ophite AOFO, and biomass bottom ash AOFA). These families of mixtures are manufactured in order to evaluate the goodness of incorporation of biomass bottom ash. The constituent materials of each family of bituminous mixtures, as well as the acronyms used for their subsequent mention, are detailed in Table 4.

Table 4. Materials conforming the different bituminous mixtures developed.

\begin{tabular}{cccc}
\hline Materials & AOFC & AOFO & AOFA \\
\hline Coarse aggregate & Ophite & Ophite & Ophite \\
Fine aggregate & Ophite & Ophite & Ophite \\
Filler & Limestone & Ophite & Biomass bottom ash \\
\hline
\end{tabular}

The grading curve of the bituminous mixtures developed should be within the grading envelope established by the Spanish regulations, Order of 2 July 1976 [49]. In order not to induce more variables that could affect the results, the grading curve used was the intermediate one of the grading envelopes for the three families of mixes manufactured. The grading curve of the three families of mixtures is detailed in Figure 1.

\section{DISCONTINUOUS GRADING BITUMINOUS MIXTURE}

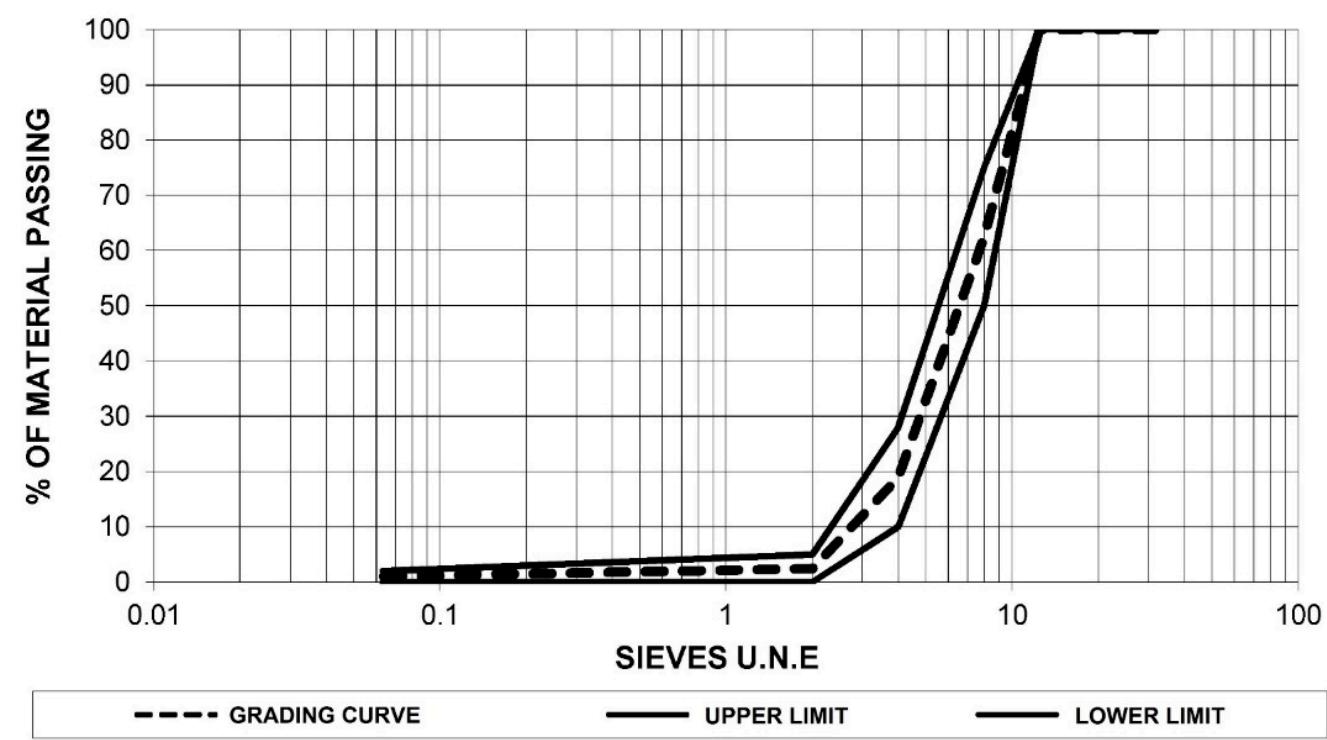

Figure 1. Grading curve of the AOFC, AOFO, and AOFA families of bituminous mixtures.

After defining the grading curve, the percentage of bitumen emulsion to be added to form the bituminous mix is calculated. It should be noted that the percentage of emulsion corresponds to a percentage of bitumen. This percentage of bitumen is the one that will exist in the mixture after the bituminous mixtures curing, that is, after the breaking of the 
emulsion, the separation of water and bitumen from the emulsion, and the evaporation of the water with the acquisition of the final characteristics of the bituminous mixture. The calculation of the percentage of residual bitumen from the percentage of emulsion is simple, since knowing the technical characteristics of the emulsion you can calculate the percentage of bitumen it contains. In this case, the bitumen emulsion used, C60BF3 MBA, contains $60 \%$ bitumen.

To calculate the bitumen percentage of the bitumen emulsion, the empirical formula provided by ATEB, Technical Association for Bitumen Emulsions [50], in its good practice guide for this type of bitumen emulsion is used. This formula [50] is based on the specific surface area of a conventional aggregate and is detailed below:

$$
B R=(K / 100) \cdot(1.5 \mathrm{~A}+2.5 \mathrm{~B}+4 \mathrm{C}+6 \mathrm{D}+9 \mathrm{E}+12 \mathrm{~F})
$$

where:

- $\quad \mathrm{BR}=$ Proportion of residual bitumen on the dry mass of the aggregates.

- $\mathrm{K}=$ Coefficient of enrichment, the value of which is 1 in the wearing course and 0.9 in the lower course.

- $\mathrm{A}=$ Proportion of aggregates retained by the sieve UNE $20 \mathrm{~mm}$.

- $\quad \mathrm{B}=$ Proportion of aggregates passing through the sieve UNE $20 \mathrm{~mm}$ and is retained by the sieve UNE $8 \mathrm{~mm}$.

- $\quad \mathrm{C}=$ Proportion of aggregates passing through the sieve UNE $8 \mathrm{~mm}$ and is retained by the sieve UNE $4 \mathrm{~mm}$.

- $\mathrm{D}=$ Proportion of aggregates passing through the sieve UNE $4 \mathrm{~mm}$ and is retained by the sieve UNE $2 \mathrm{~mm}$.

- $\quad \mathrm{E}=$ Proportion of aggregates passing through the sieve UNE $2 \mathrm{~mm}$ and is retained by the sieve UNE $0.063 \mathrm{~mm}$.

- $\mathrm{F}=$ Proportion of aggregates passing through the sieve UNE $0.063 \mathrm{~mm}$.

According to the empirical formula detailed above, the percentage of residual bitumen for the three families of bituminous mixtures is 3.9\% over aggregate, corresponding to an emulsion percentage of $6.5 \%$ over aggregate. Once the initial bitumen and bitumen emulsion percentages were determined, the families of bituminous mixtures were formed with increasing emulsion percentages of $0.5 \%$ from the initial percentage determined. These mixtures were evaluated by means of the binder drainage test, according to the UNE-EN 12697-18 standard [51]. The purpose of this test is to obtain the percentage of bitumen that produces binder drainage problems, and consequently, its use would produce problems in the bleeding infrastructure and plastic deformations with high probability. Therefore, the first percentage of emulsion of each mix family that produces binder drainage will be the limiting one, this percentage not being suitable and using as maximum just the previous one.

Subsequently, and in order to evaluate the compatibility of the bitumen with the bitumen emulsion, the coating test was carried out according to the NLT-196/84 standard [52], for all the emulsion percentages studied above and for the three families. In this way, the percentage of aggregate covered by the emulsion can be evaluated. This simple test provides important qualitative information on the expected behavior of the bituminous mixture.

Once the viable emulsion percentages were determined for the three asphalt mixtures (AOFC, $\mathrm{AOFO}$, and $\mathrm{AOFB}$ ), these being the maximum emulsion percentages that do not produce binder drainage problems, the different families of mixtures were formed with this emulsion percentage and the defined particle size. It should be noted that the maximum percentage that does not produce binder drainage problems has been selected as the optimum emulsion percentage. This is because the binder, together with the filler, produces the mastic of the bituminous mixes. This mastic is in charge of coating the aggregates and supporting the repeated tensile loads. Consequently, a higher percentage of bitumen will create a more elastic and better-quality mastic for a longer working life. 
The test samples manufactured for the subsequent tests, from each family and with the maximum percentage of bitumen emulsion, were Marshall test samples. These test samples were manufactured with the established percentages of each material and according to the standard UNE-EN 12697-30 [53], being compacted with 50 blows per face. Subsequently, the test samples were subjected to a curing process to eliminate water from the bitumen emulsion. This process consisted of curing for 2 days at a temperature of $75 \pm 2{ }^{\circ} \mathrm{C}$ and 5 more days at a temperature of $90 \pm 2{ }^{\circ} \mathrm{C}$, confirming that there was no binder runoff during curing.

After curing, the test samples were stripped and subjected to a series of physical tests to determine the general physical properties of the families of bituminous mixtures made with limestone filler, ophite, and biomass bottom ash. The first test samples were tested for maximum density, according to standard UNE-EN 12697-5 [54]; bulk density, according to standard UNE-EN 12697-6 [55]; and voids content in the mixture, according to standard UNE-EN 12697-8 [56].

Subsequently, in order to determine the resistance of the bituminous mixtures to fracture and aggregate pull-out, the particle loss of porous asphalt specimens was tested in accordance with standard UNE-EN 12697-17 [57] for all families of mixtures. In turn, in order to evaluate the influence of water on the bituminous mixture and, consequently, to determine the compatibility between the aggregate and the emulsion, the same type of test was carried out with immersion in water at $45 \pm 1{ }^{\circ} \mathrm{C}$ for $24 \mathrm{~h}$, according to standard NLT-362/92 [58].

In this way, the quality of the mastic conformed with the filler and bitumen of the emulsion could be determined. However, due to the incorporation of high percentages of bitumen, the problem of plastic deformations in the infrastructure can occur. To avoid this and to quantify the resistance of the mix at high temperatures, the Marshall test was carried out in accordance with the UNE-EN 12697-34 standard [59]. This test consists of subjecting the manufactured samples of each family to a temperature of $60 \pm 2{ }^{\circ} \mathrm{C}$ for a determined period of time and then testing them in indirect traction to determine their resistance.

Finally, the results obtained from the different families of bituminous mixtures (AOFC, AOFO, and AOFA) were compared, obtaining the differences between the physical and mechanical properties and, consequently, the suitability of biomass bottom ash as a filler for bituminous mixtures.

\section{Results}

The results of the tests mentioned in the methodology, as well as their discussion, are shown in the following sections.

\subsection{Characterization of Biomass Bottom Ash}

First, the chemical and physical characterization of the biomass bottom ash was carried out. As mentioned above, biomass bottom ash is a mainly inorganic material. Therefore, it is essential to perform the X-ray fluorescence test in order to identify the chemical elements of higher atomic weight that exist in the sample. The X-ray fluorescence test results, in the form of oxides, in the biomass bottom ash from this research, and other biomass bottom ashes that are derived from similar biomass [60], olive-pruning remains and vegetable-fat wastes, are shown in Table 5.

The X-ray fluorescence test reflects a high percentage of potassium. This is to be expected, taking into account that the biomass bottom ash analyzed comes from the combustion of almond shells and alpeorujo. This high percentage of potassium conditions further research into the use of ash as a fertilizer. At the same time, elements such as calcium, silicon, magnesium, and phosphorus are substantially present in the sample. These chemical elements are common in the biomass bottom ashes analyzed by different authors [60] and do not pose a problem in themselves; moreover, they will condition the desired cementitious characteristics of the ashes corroborated in different investigations. 
In addition, there are also percentages of sulfur and chlorine, which were subsequently analyzed by leachate tests to determine whether contaminating leachates are produced.

Table 5. X-ray fluorescence results of biomass bottom ash from this research and biomass bottom ash from the combustion of olive-pruning remains and vegetable-fat wastes [60].

\begin{tabular}{ccc}
\hline Compound & BBA, Wt. \% & BBA [60], Wt. \% \\
\hline $\mathrm{K}_{2} \mathrm{O}$ & $45.2 \pm 0.25$ & $16.47 \pm 0.19$ \\
$\mathrm{CaO}$ & $8.98 \pm 0.14$ & $25.29 \pm 0.22$ \\
$\mathrm{SiO}_{2}$ & $8.96 \pm 0.14$ & $26.21 \pm 0.22$ \\
$\mathrm{SO}_{3}$ & $6.43 \pm 0.12$ & $0.420 \pm 0.021$ \\
$\mathrm{Cl}$ & $4.72 \pm 0.11$ & $0.1750 \pm 0.0087$ \\
$\mathrm{MgO}$ & $4.04 \pm 0.1$ & $7.58 \pm 0.13$ \\
$\mathrm{P}_{2} \mathrm{O}_{5}$ & $3.56 \pm 0.09$ & $6.03 \pm 0.12$ \\
$\mathrm{Al}_{2} \mathrm{O}_{3}$ & $1.64 \pm 0.06$ & $4.54 \pm 0.10$ \\
$\mathrm{Fe}_{2} \mathrm{O}_{3}$ & $0.864 \pm 0.043$ & $1.97 \pm 0.07$ \\
$\mathrm{Na}_{2} \mathrm{O}$ & $0.623 \pm 0.031$ & $0.274 \pm 0.024$ \\
$\mathrm{ZnO}_{\mathrm{TiO}}$ & $0.197 \pm 0.0098$ & $0.0099 \pm 0.0021$ \\
$\mathrm{SrO}$ & $0.0728 \pm 0.0036$ & $0.240 \pm 0.012$ \\
$\mathrm{MnO}_{\mathrm{Rb}}$ & $0.0533 \pm 0.0027$ & $0.1340 \pm 0.0067$ \\
$\mathrm{NiO}_{\mathrm{CuO}}$ & $0.0312 \pm 0.002$ & $0.1010 \pm 0.0050$ \\
$\mathrm{Cr}_{2} \mathrm{O}_{3}$ & $0.0237 \pm 0.0037$ & - \\
\end{tabular}

It should be noted that chemical elements have greater or lesser activity, and even produce lesser or greater contamination, depending on the chemical compound in which they are combined. Therefore, it is essential to determine the chemical compounds present in the sample. This analysis is carried out by means of the X-ray diffraction test, reflecting the results shown in the diffractogram in Figure 2.

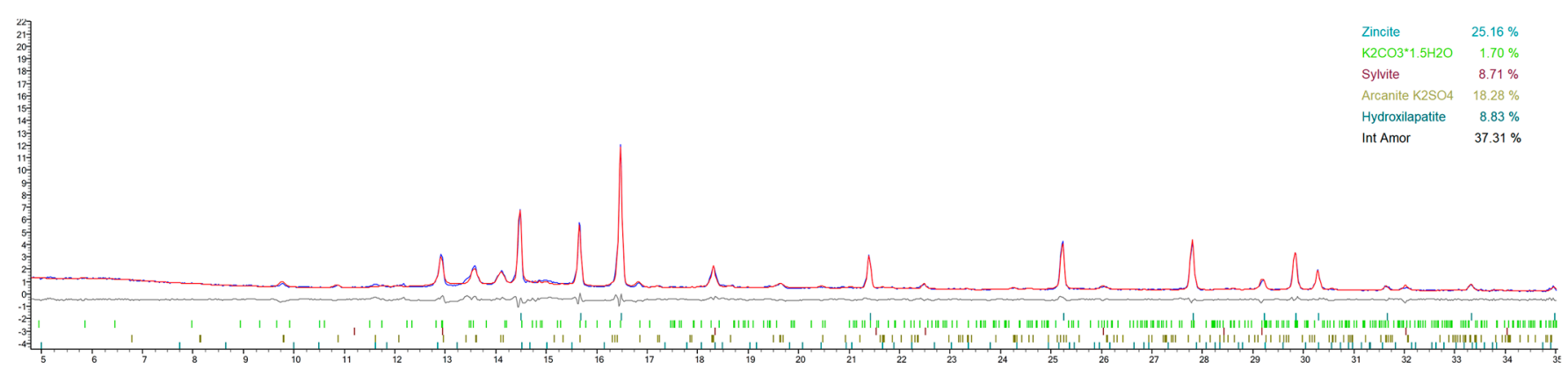

Figure 2. Results of X-ray diffraction of biomass bottom ash.

The diffractogram of the biomass bottom ash shows a high content of amorphous or non-diffracting material. The main phases identified are silicates, potassium carbonate, sylvite, and arcanite. The silicates present seem to be responsible for providing the cementitious characteristics of the biomass bottom ashes corroborated by different investigations. In addition, the existence of potassium carbonate ensures the dimensional stability of the ashes, with no expansivity problems. This is because the expansivity occurs during the carbonation process and not afterwards. The existence of sylvite and arcanite coincides with the results obtained in the X-ray fluorescence test, since previously a significant percentage of chlorine and sulfur could be observed.

The last of the chemical tests is the leachate test, since although there are no significant percentages of heavy metals in the biomass bottom ash, there are other elements such as sulfur and chlorine that must be controlled in order not to cause significant environmental 
problems. The results of the leachate test, carried out according to the standard mentioned in the methodology, are shown in Table 6.

Table 6. Concentration of chemical elements in biomass bottom ash leachate compared to regulatory limits, UNE-EN 12457-3 standard.

\begin{tabular}{ccc}
\hline Element & BBA, $\boldsymbol{\mu g} / \mathbf{k g}$ & Maximum Limits, $\boldsymbol{\mu g} / \mathbf{k g}$ \\
\hline $\mathrm{Ba}$ & $182 \pm 5$ & 17,000 \\
$\mathrm{Cd}$ & $2 \pm 1$ & 9 \\
$\mathrm{Cr}$ & $2 \pm 1$ & 500 \\
$\mathrm{Mo}$ & $1 \pm 1$ & 500 \\
$\mathrm{Ni}$ & $9 \pm 1$ & 400 \\
$\mathrm{~Pb}$ & $1 \pm 1$ & 500 \\
$\mathrm{Se}$ & $2 \pm 1$ & 100 \\
$\mathrm{~V}$ & $3 \pm 1$ & 1300 \\
$\mathrm{Zn}$ & $12 \pm 1$ & 1200 \\
$\mathrm{As}$ & $2 \pm 1$ & 500 \\
$\mathrm{Cu}$ & $9 \pm 1$ & 2000 \\
$\mathrm{Hg}$ & - & 10 \\
$\mathrm{Sb}$ & $1 \pm 1$ & 60 \\
Chloride & $134,000 \pm 3000$ & 800,000 \\
Sulfates & $86,000 \pm 3000$ & 377,000 \\
\hline
\end{tabular}

The leachate test shows that the concentration of the pollutant elements set is below the limits established by the Spanish-European regulations for waste [61]. It should be noted that the chlorine and sulfur elements detected in the X-ray fluorescence and X-ray diffraction tests have resulted in reduced leaching of chlorides and sulfates. Heavy metals are found in low concentration, mainly because these elements are difficult to find in the biomass used.

Once the physical properties of the biomass bottom ashes were analyzed, the physical properties of the ashes were determined. The first of the tests carried out was the determination of the grading curve by means of the laser particle size test. The grading curve of the biomass bottom ash, after treatment, is shown in Figure 3.

\section{BIOMASS BOTTOM ASH GRADING CURVE}

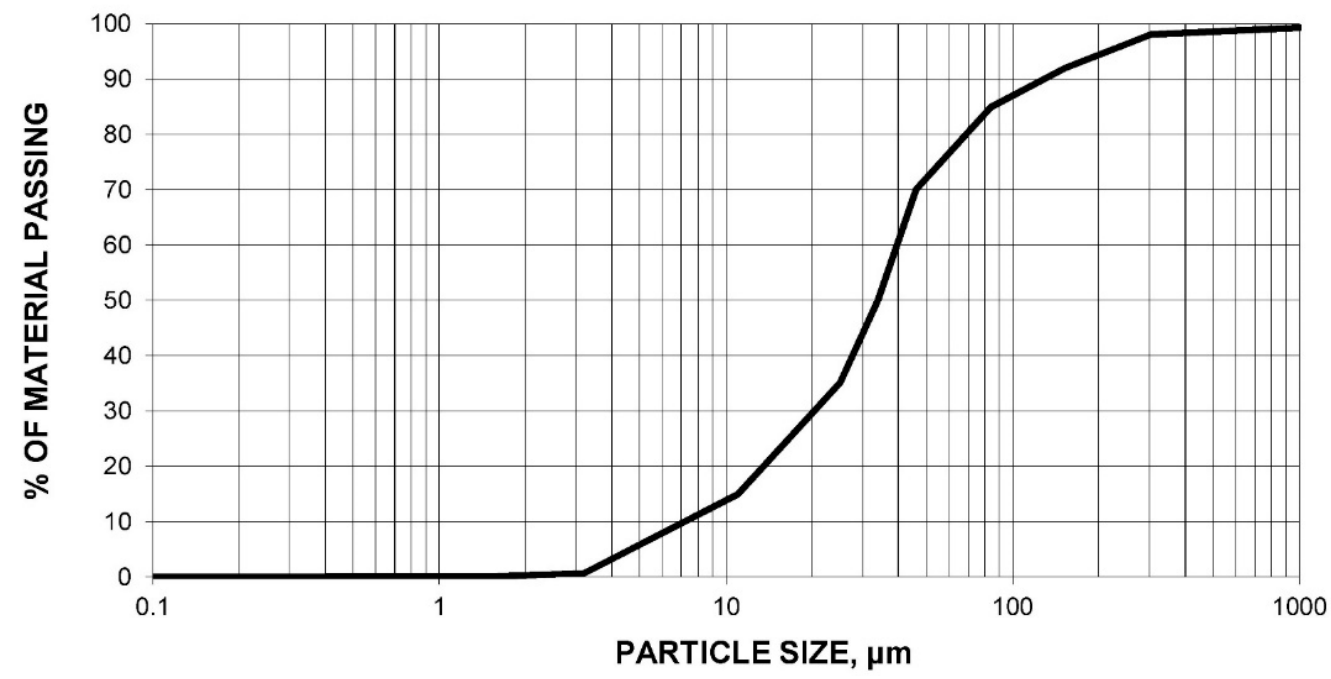

Figure 3. Biomass bottom ash grading curve.

The grading curve of biomass bottom ash represents a continuous grading. Particles smaller than $0.063 \mathrm{~mm}$ represent a percentage higher than the $70 \%$ established by European regulations, and there are no particles larger than $2 \mathrm{~mm}$. Therefore, and based on the 
grading curve analyzed for the biomass bottom ash, it can be stated that the grading curve of the ashes after treatment is suitable for use as a filler in bituminous mixtures.

Subsequently, in order to characterize the surface of the biomass bottom ashes at high magnifications and to provide valuable qualitative information, the ashes were analyzed by scanning electron microscopy. The images obtained from the scanning electron microscope are shown in Figure 4.
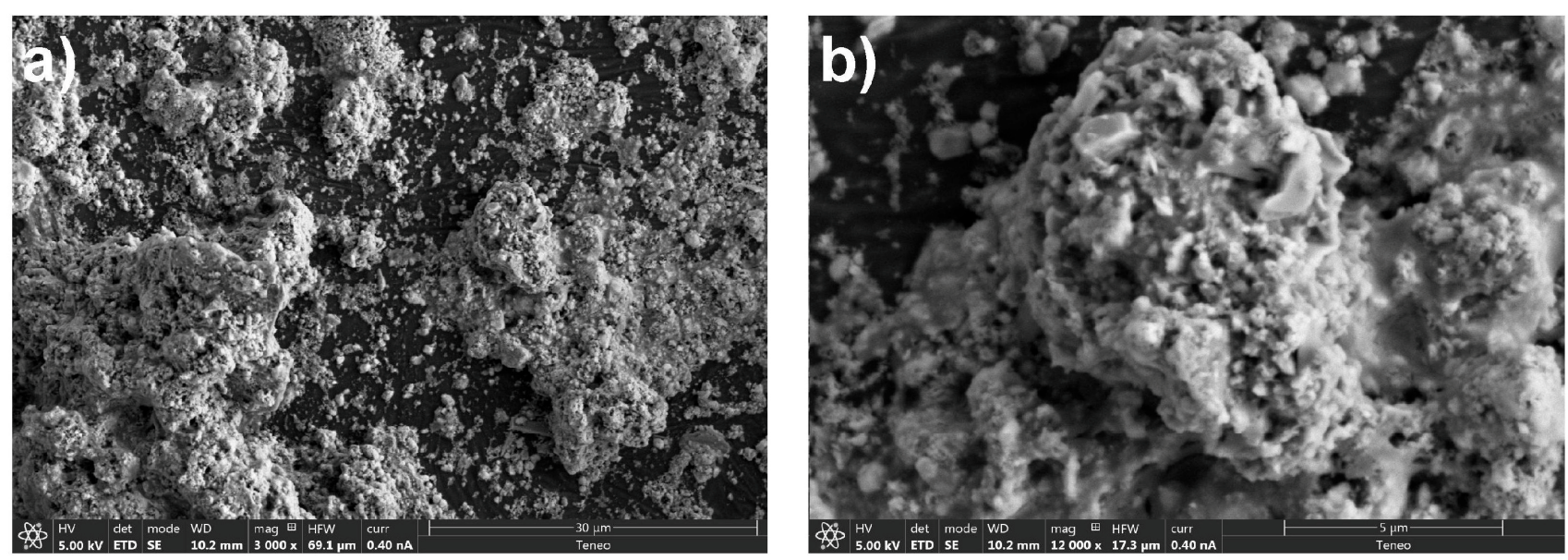

Figure 4. Scanning electron microscope images of biomass bottom ash at different magnifications in the secondary option. (a) 3000X. (b) 12000X.

Scanning electron microscope images of biomass bottom ash reflect a very irregular ash surface. Micropores and cavities abound on the surface of the ashes, which have a significant influence on the higher specific surface area. The existence of a higher specific surface conditions a higher bitumen absorption in bituminous mixtures. As a result, a higher quality mastic is formed, capable of enveloping the aggregates and making possible the tensile strength of the bituminous mix. In turn, a higher percentage of bitumen also conditions a longer service life, since there is a higher proportion of mastic capable of withstanding repeated traffic loads.

On the other hand, in order to fully determine the physical properties of the biomass bottom ash, particle density, bulk density in kerosene, and plasticity index tests were carried out, according to the standards mentioned in the methodology. The results of these tests are shown in Table 7.

Table 7. Density and plasticity tests for the fine portion of biomass bottom ash.

\begin{tabular}{ccc}
\hline Test & Standard & Value/Unit \\
\hline Particle density & UNE-EN 1097-7 [30] & $2.54 \pm 0.07 \mathrm{t} / \mathrm{m}^{3}$ \\
Bulk density & UNE-EN 1097-3 [31] & $0.45 \pm 0.01 \mathrm{t} / \mathrm{m}^{3}$ \\
Plasticity index & UNE-EN ISO 17892-12 [32] & No plasticity \\
\hline
\end{tabular}

The particle density of biomass bottom ash is similar to that of a commercial filler, $2.65 \mathrm{t} / \mathrm{m}^{3}$. Therefore, it is not necessary to correct the volumetric dosage of ash as a filler, and its incorporation is similar to that of other conventional materials. The bulk density in kerosene, although complying with the limits established by the regulations, shows the high specific surface area of biomass bottom ash compared to other commercial fillers, which obtain bulk densities around $0.7 \mathrm{t} / \mathrm{m}^{3}$. This lower density, as detailed above, influences a higher percentage of bitumen absorption, since a greater mass of binder is necessary to cover the entire specific surface of the biomass bottom ash. This fact, far from being a problem, leads to the creation of a higher quality mastic, due to the cementitious properties of the ashes and the higher percentage of bitumen, conditioning a higher tensile strength of the bituminous mix under repeated traffic loads, fatigue. Finally, the plasticity 
index shows the non-existence of clayey particles that could cause subsequent expansivity problems, since the result is null. This is to be expected if one takes into account the cementitious properties of biomass bottom ashes corroborated by different authors.

Based on the results of the chemical and physical characteristics of biomass bottom ashes, it can be affirmed that their use as filler in bituminous mixtures is acceptable according to Spanish-European regulations.

\subsection{Conformation of Bituminous Mixtures and Tests}

After analyzing the chemical and physical properties of the biomass bottom ash, the different bituminous mixtures were made with the three types of filler defined in Table 4 and with the particle size detailed in Figure 1. The bituminous mixtures were made with increasing percentages of $0.5 \%$ of emulsion from $6.5 \%$ on aggregate, fixed by the ATEB equation, up to the production of binder drainage. The results of the binder drainage test are shown in Table 8.

Table 8. Binder drainage test for different bituminous mixes (AOFC, AOFO, and AOFA) with increasing emulsion percentages.

\begin{tabular}{ccccccc}
\hline \multicolumn{7}{c}{ \% of Bitumen Emulsion on Aggregate } \\
\hline Family & $\mathbf{6 . 5 0 \%}$ & $\mathbf{7 \%}$ & $\mathbf{7 . 5 0 \%}$ & $\mathbf{8 \%}$ & $\mathbf{8 . 5 0} \%$ & $\mathbf{9 \%}$ \\
\hline AOFC & Acceptable & Acceptable & Unacceptable & Unacceptable & Unacceptable & Unacceptable \\
AOFO & Acceptable & Acceptable & Unacceptable & Unacceptable & Unacceptable & Unacceptable \\
AOFA & Acceptable & Acceptable & Acceptable & Acceptable & Acceptable & Unacceptable \\
\hline
\end{tabular}

The results of the binder drainage test show that the bituminous mixtures made with limestone filler (AOFC) and ophite filler (AOFO) absorb a maximum percentage of bitumen emulsion of $7 \%$ of aggregate, $4.2 \%$ of bitumen, without causing bleeding problems. On the other hand, the bitumen emulsion mixture made with biomass bottom ash filler (AOFA) absorbs a higher percentage of bitumen emulsion, that is, $8.5 \%$ of aggregate, or $5.1 \%$ of residual bitumen. This fact corroborates the results of the bulk density tests in kerosene and scanning electron microscopy, which showed a higher specific surface area of the ashes. This higher percentage of bitumen will condition a better tensile behavior of the bituminous mixture made with biomass bottom ash; however, plastic deformations should be evaluated to prevent the higher percentage of bitumen from causing this problem.

Subsequently, the coating test was carried out to determine the compatibility of the aggregates with the emulsion. Initially, the coating test was performed for the AOFA mixes up to the acceptable percentage determined above and immediately above. The images of the coating test are shown in Figure 5.

The coating test of the asphalt mixtures made with biomass bottom ash filler (AOFA) shows how the complete covering of the aggregate by the emulsion occurs from a percentage of $8 \%$, corroborating the existence of a higher specific surface area of the ashes and, consequently, the need for a higher percentage of emulsion.

The coating test for the families of bituminous mixtures made with limestone filler $(\mathrm{AOFC})$ is shown in Figure 6.

The coating test for the AOFC bituminous mix shows that from the initial emulsion percentage of $6.5 \%$ there is a complete covering of the aggregate by the emulsion, accepting only an increase in emulsion percentage of $0.5 \%$. The coating tests for this family and for all the emulsion percentages evaluated are acceptable.

Finally, the coating test for the bituminous mixture made with ophite filler is shown in Figure 7. 


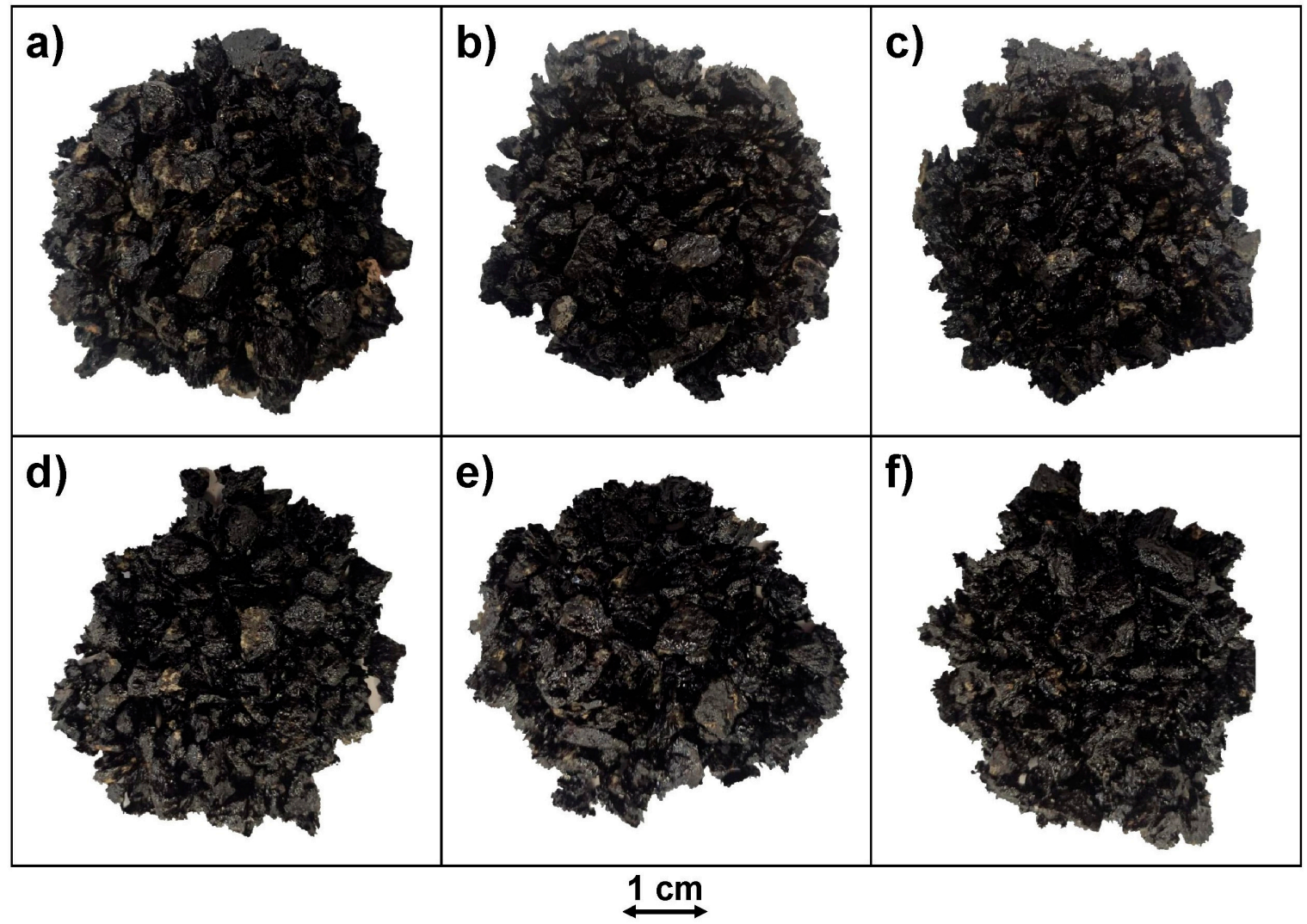

Figure 5. Coating test of bituminous mixtures conformed with ophite coarse and fine aggregate and biomass bottom ash filler AOFA. (a) 6.5\% residual bitumen, (b) 7\% residual bitumen, (c) 7.5\% residual bitumen, (d) 8\% residual bitumen, (e) $8.5 \%$ residual bitumen, and (f) $9 \%$ residual bitumen.
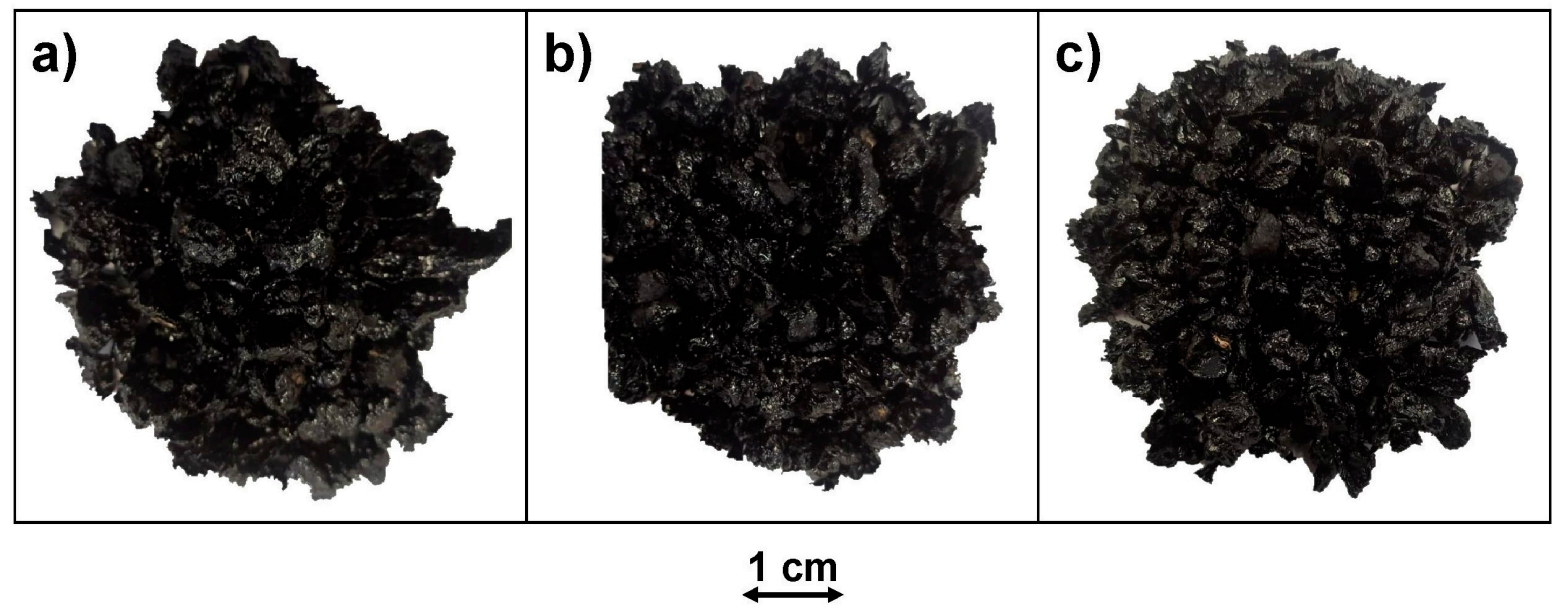

Figure 6. Coating test of bituminous mixtures conformed with ophite coarse and fine aggregate and limestone filler AOFC.

(a) $6.5 \%$ residual bitumen, (b) 7\% residual bitumen, (c) 7.5\% residual bitumen.

The coating test of the bituminous mixture made with ophite filler shows, like the one made with limestone filler, that the coating of the aggregate by the emulsion is adequate in all percentages. Consequently, the same conclusions can be obtained as those detailed above.

Based on the results obtained, test samples of Marshall type bituminous mixtures were conformed with the maximum emulsion percentages that did not produce bleeding of bitumen, since, as could be seen with the coating test for all these emulsion percentages, the 
covering of the aggregate by the emulsion was optimal in the three families. The bitumen emulsion and residual bitumen percentages are shown in Table 9.

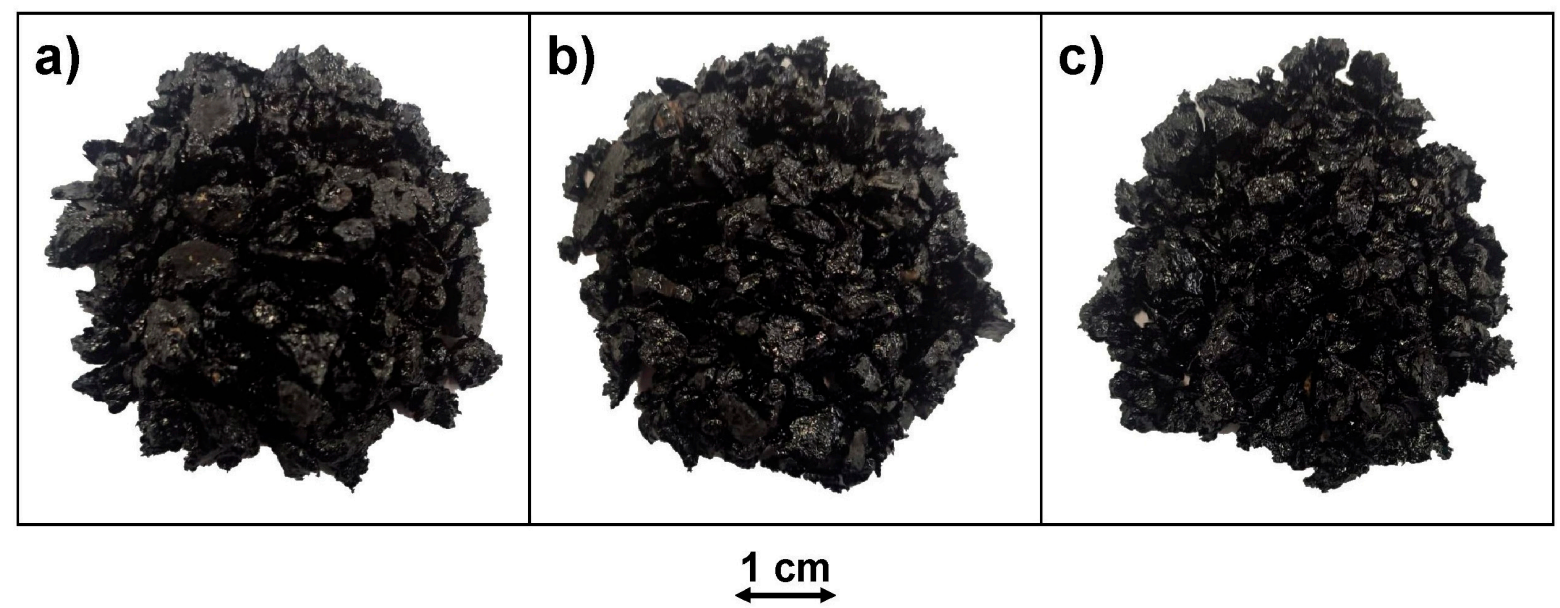

Figure 7. Coating test of bituminous mixtures conformed with ophite coarse and fine aggregate and ophite filler AOFC. (a) $6.5 \%$ residual bitumen, (b) $7 \%$ residual bitumen, (c) $7.5 \%$ residual bitumen.

Table 9. Optimum percentage of emulsion and residual bitumen for AOFC, AOFO, and AOFA bituminous mixes.

\begin{tabular}{ccc}
\hline Family & \% Emulsion on Aggregate & \% Bitumen on Aggregate \\
\hline AOFC & 7 & 4.2 \\
AOFO & 7 & 4.2 \\
AOFA & 8.5 & 5.1 \\
\hline
\end{tabular}

Once the optimum bitumen emulsion percentages were defined for each family of bituminous mixtures, several test samples of each family were manufactured with the grading defined in Figure 1 and the percentage of binder determined in Table 9. These Marshall type test samples were manufactured and cured according to the procedure described in the methodology. The test samples from each family were physically and mechanically characterized, showing the results for the tests detailed in the methodology shown in Table 10.

Table 10. Physical and mechanical tests of the different families of specimens made with the three fillers, AOFC, AOFO, and AOFA.

\begin{tabular}{ccccc}
\hline Test & Standard & AOFC & AOFO & AOFA \\
\hline Bitumen emulsion, \% & - & 7 & 7 & 8.5 \\
Bitumen, \% & - & 4.2 & 4.2 & 5.1 \\
Maximum density, kg/m ${ }^{3}$ & UNE-EN 12697-5 [54] & $2640 \pm 65$ & $2641 \pm 65$ & $2625 \pm 62$ \\
Bulk density, kg/m 3 & UNE-EN 12697-6 [55] & $2461 \pm 88$ & $2460 \pm 87$ & $2453 \pm 87$ \\
Void content, \% & UNE-EN 12697-8 [56] & $6.77 \pm 0.25$ & $6.87 \pm 0.24$ & $6.57 \pm 0.23$ \\
Particle loss, \% & UNE-EN 12697-17 [57] & $83 \pm 3$ & $89 \pm 3$ & $93 \pm 4$ \\
Particle loss with immersion, $\%$ & NLT-362/92 [58] & $76 \pm 2$ & $80 \pm 3$ & $86 \pm 3$ \\
Marshall Resistance, N & UNE-EN 12697-34 [59] & $7671 \pm 274$ & $8598 \pm 280$ & $10,325 \pm 368$ \\
\hline
\end{tabular}

As can be seen, the density of the bituminous mixtures conformed with ophite filler (AOFO) is higher than that of the other bituminous mixtures, but very similar to the bituminous mixtures conformed with limestone filler (AOFC). This is due to the fact that the density of the ophite filler is higher than that of the other aggregates and that the percentage of filler in the mixture is very small, so that the mixture with limestone filler obtains similar results. In turn, the bituminous mixture conformed with biomass bottom 
ash filler (AOFA) has a lower maximum density than the other two types of mixtures, due to the lower density of the ashes and the higher percentage of binder.

The bulk density of the bituminous mixtures is the density taking into account the air voids in the mixture. In this case, the three bituminous mixtures obtain very similar results, highlighting the lower density of the mixture conformed with biomass bottom ash (AOFA). This density reflects that the compactibility of the bituminous mixtures is similar, so it will directly influence the voids content of the bituminous mixture.

Consequently, the void content of the three families of bituminous mixtures is similar, since the variations in the results obtained are minimal. This fact reflects that the incorporation of a higher percentage of emulsion in the mixture with biomass bottom ash filler (AOFA), as well as its lower density, does not negatively influence the production of a more closed bituminous mixture. Therefore, it can be stated that with these conditions, the AOFA bituminous mixture manages to obtain physical properties similar to traditional bituminous mixtures, since the void content is the most important physical property to be taken into account. This fact derives from the fact that the percentage of voids in the mix influences drainage, pavement friction, and even noise absorption. However, this high void content can cause cracking of the bituminous mix, and even the aggregates to pull out if the mastic formed is not of sufficient quality to hold the coarse aggregates together. Therefore, it is essential to carry out the particle loss test to corroborate that there are no problems of this type. In addition, in order to evaluate the mastic under adverse conditions and the effect of water on the bituminous mix, the same particle loss test was performed after immersing the test samples in water at a temperature of $45 \pm 1{ }^{\circ} \mathrm{C}$ for $24 \mathrm{~h}$.

Spanish regulations stipulate that the particle loss test results must be less than $25 \%$ to be acceptable; consequently, all families of bituminous mixtures provide adequate results with and without immersion. The lower percentage of particle loss of bituminous mixtures made with biomass bottom ash filler is noteworthy. This is because the higher percentage of emulsion that is capable of absorbing the ashes, as well as the cementitious characteristics corroborated by different authors, leads to the creation of mastic of a higher quality capable of enveloping and holding the aggregates together.

However, a higher percentage of bitumen can condition the production of plastic deformations in the bituminous mix. This is totally unacceptable and would render the infrastructure unusable. To avoid the production of plastic deformations, the Marshall test was carried out on all the families of bituminous mixtures.

The Marshall stability or resistance of the family of bituminous mixtures made with biomass bottom ash filler (AOFA) is higher than that obtained with the other types of filler, indirectly reflecting the cementitious characteristics of the biomass bottom ash. Consequently, the higher percentage of bitumen of the AOFA family, absorbed by the ashes, develops better fracture behavior and plastic deformations than the other commercial fillers, providing in turn a higher resistance to repeated traffic loads thanks to a higher quality mastic. It should be noted that all the samples have acceptable Marshall resistance values, since the values obtained are higher than the $7.5 \mathrm{kN}$ established by the standards.

In short, it can be stated that bituminous mixtures of discontinuous grading with bitumen emulsion and biomass bottom ash have a higher percentage of bitumen, allowing a better performance in the particle loss test, greater Marshall stability, and physical properties similar to those obtained with commercial fillers.

\section{Conclusions}

The results of the tests mentioned in the methodology lead to a series of partial conclusions that converge in the verification of the final hypothesis. The final hypothesis of this research is the study of the viability of biomass bottom ashes as filler in bituminous mixtures of discontinuous grading and bitumen emulsion. Therefore, we proceed to define the partial conclusions:

- The chemical composition of biomass bottom ash reflects that it is a mainly inorganic material, with a low percentage of organic matter. The main chemical elements are 
potassium, calcium, silicon, sulfur, chlorine, magnesium, and phosphorus, these elements being usual in other types of biomass ashes.

- The main chemical compounds of biomass bottom ash are silicates, potassium carbonate, sylvite, and arcanite. These compounds are responsible for the cementitious properties discussed by different authors.

- The biomass bottom ash leachate test showed a low concentration in the leachate of heavy metals, as well as carbon and sulfur. Consequently, their use in bituminous mixtures is acceptable without producing environmental pollution problems, especially when the ashes are coating by bitumen.

- The grading of the biomass bottom ash after treatment is suitable for use as a filler in bituminous mixtures.

- The particle density and bulk density in kerosene of the biomass bottom ashes are acceptable according to the standards, highlighting the higher specific surface area of the ashes reflected in the bulk density and scanning electron microscope test. In addition, the ashes do not show plasticity.

- The bituminous mixtures conformed with biomass bottom ash filler obtain similar physical properties, void content, to mixtures conformed with limestone filler and ophite filler.

- The mixtures conformed with biomass bottom ash have a lower particle loss due to the existence of a quality mastic that coats the aggregates and holds them together under tensile loads.

- The Marshall test showed that bituminous mixes with biomass bottom ash have higher strength and, consequently, better plastic deformation behavior, even with a higher percentage of bitumen, than mixes with ophite filler and limestone filler.

Based on the partial conclusions, it can be stated that biomass bottom ash has acceptable chemical and physical characteristics for use as a filler in bituminous mixtures. In addition, its use as a filler in discontinuous grading bituminous mixtures with bitumen emulsion develops a quality mastic capable of providing better tensile strength, better behavior to plastic deformations, higher bitumen absorption, and physical properties similar to traditional mixtures. At the same time, it should be noted that the use of a waste product that is currently unused for the conforming of bituminous mixtures avoids the deposition of this by-product in landfills, avoids the extraction of new raw materials, and creates sustainable materials for construction.

Author Contributions: Conceptualization, F.A.C.-I., F.J.I.-G., J.M.T.-S., and J.S.-M.; methodology, F.A.C.-I., F.J.I.-G., J.M.T.-S., and J.S.-M.; software, J.M.T.-S. and J.S.-M.; validation, F.A.C.-I. and F.J.I.G.; formal analysis, F.A.C.-I. and F.J.I.-G.; investigation, J.M.T.-S. and J.S.-M.; resources, F.A.C.-I.; data curation, F.J.I.-G.; writing—original draft preparation, J.S.-M.; writing—review and editing, J.M.T.-S.; visualization, J.M.T.-S.; supervision, F.A.C.-I.; project administration, J.S.-M.; funding acquisition, F.A.C.-I. All authors have read and agreed to the published version of the manuscript.

Funding: This research received no external funding.

Institutional Review Board Statement: Not applicable.

Informed Consent Statement: Not applicable.

Data Availability Statement: Data are contained within the article.

Acknowledgments: The technical and human support provided by CICT of Universidad de Jaén (UJA, MINECO, Junta de Andalucía, FEDER) is gratefully acknowledged.

Conflicts of Interest: The authors declare no conflict of interest. 


\section{References}

1. James, K.A.; Thring, W.R.; Helle, S.; Ghuman, S.H. Ash Management Review: Applications of Biomass Bottom Ash. Energies 2012, 5, 3856-3873. [CrossRef]

2. Capros, P.; Mantzos, L.; Tasios, N.; De Vita, A.; Kouvaritakis, N. EU Energy Trends to 2030: Update 2009; Publications Office of the European Union: Luxembourg; Brussels, Belgium, 2010; ISBN 9279161911. Available online: https:/ / ec.europa.eu/energy/sites/ ener/files/documents/trends_to_2030_update_2009.pdf (accessed on 2 April 2021).

3. Figueroa Luque, E.; Morillo Aguado, J. Estudio Técnico-Económico Para la Implantación de una Planta de Generación de Energía Eléctrica a Partir de Biomasa en Andalucía; University of Seville: Seville, Spain, 2013. Available online: https://idus.us.es/handle/11441/26821 (accessed on 2 April 2021).

4. Rosúa, J.M.; Pasadas, M. Biomass potential in Andalusia, from grapevines, olives, fruit trees and poplar, for providing heating in homes. Renew. Sustain. Energy Rev. 2012, 16, 4190-4195. [CrossRef]

5. Fernando, S.N.; Daniel, G.G.; Rezeau, A. Energía de la Biomasa II (Energías Renovables); Prensas de la Universidad de Zaragoza: Zaragoza, Spain, 2010; ISBN 978-84-15031-01-7.

6. García Calvo, J.L.; Hidalgo, A.; Alonso, M.C.; Luxán, M.P.; Fernández Luco, L. Characterization of waste from biomass combustion processes, viability of use as construction materials. In Proceedings of the XI National Congress of Materials, Zaragoza, Spain, 23-25 June 2010.

7. Rajamma, R.; Ball, R.J.; Tarelho, L.A.C.; Allen, G.C.; Labrincha, J.A.; Ferreira, V.M. Characterisation and use of biomass fly ash in cement-based materials. J. Hazard. Mater. 2009, 172, 1049-1060. [CrossRef] [PubMed]

8. Porcino, D.D.; Mauriello, F.; Bonaccorsi, L.; Tomasello, G.; Paone, E.; Malara, A. Recovery of Biomass Fly Ash and HDPE in Innovative Synthetic Lightweight Aggregates for Sustainable Geotechnical Applications. Sustainability 2020, 12, 6552. [CrossRef]

9. Omran, A.; Soliman, N.; Xie, A.; Davidenko, T.; Tagnit-Hamou, A. Field trials with concrete incorporating biomass-fly ash. Constr. Build. Mater. 2018, 186, 660-669. [CrossRef]

10. Carrillo-Beltran, R.; Corpas-Iglesias, F.A.; Terrones-Saeta, J.M.; Bertoya-Sol, M. New geopolymers from industrial by-products: Olive biomass fly ash and chamotte as raw materials. Constr. Build. Mater. 2021, 272, 121924. [CrossRef]

11. Ondrasek, G.; Zovko, M.; Kranjčec, F.; Savić, R.; Romić, D.; Rengel, Z. Wood biomass fly ash ameliorates acidic, low-nutrient hydromorphic soil \& reduces metal accumulation in maize. J. Clean. Prod. 2021, 283, 124650.

12. Liang, G.; Li, Y.; Yang, C.; Zi, C.; Zhang, Y.; Hu, X.; Zhao, W. Production of biosilica nanoparticles from biomass power plant fly ash. Waste Manag. 2020, 105, 8-17. [CrossRef]

13. Cabrera, M.; Rosales, J.; Ayuso, J.; Estaire, J.; Agrela, F. Feasibility of using olive biomass bottom ash in the sub-bases of roads and rural paths. Constr. Build. Mater. 2018, 181, 266-275. [CrossRef]

14. Cabrera, M.; Díaz-López, J.L.; Agrela, F.; Rosales, J. Eco-Efficient Cement-Based Materials Using Biomass Bottom Ash: A Review. Appl. Sci. 2020, 10, 8026. [CrossRef]

15. Pomponi, F.; Stephan, A. Water, energy, and carbon dioxide footprints of the construction sector: A case study on developed and developing economies. Water Res. 2021, 194, 116935. [CrossRef]

16. Lee, J.; Madanat, S. Optimal policies for greenhouse gas emission minimization under multiple agency budget constraints in pavement management. Transp. Res. Part D Transp. Environ. 2017, 55, 39-50. [CrossRef]

17. Alhazmi, H.; Shah, S.A.R.; Basheer, M.A. Performance Evaluation of Road Pavement Green Concrete: An Application of Advance Decision-Making Approach before Life Cycle Assessment. Coatings 2021, 11, 74. [CrossRef]

18. Pasandín, A.R.; Pérez, I.; Gómez-Meijide, B. Performance of High Rap Half-Warm Mix Asphalt. Sustainability 2020, $12,10240$. [CrossRef]

19. Terrones-Saeta, J.M.; Iglesias-Godino, F.J.; Corpas-Iglesias, F.A.; Martínez-García, C. Study of the Incorporation of Ladle Furnace Slag in the Manufacture of Cold In-Place Recycling with Bitumen Emulsion. Materials 2020, 13, 4765. [CrossRef] [PubMed]

20. Terrones-Saeta, J.M.; Suárez-Macías, J.; Iglesias-Godino, F.J.; Corpas-Iglesias, F.A. Development of Slurry Surfacing with Electric Arc Furnace Slag for Pavements with Friction Problems. Minerals 2020, 10, 878. [CrossRef]

21. Celauro, C.; Teresi, R.; Graziano, F.; La Mantia, F.P.; Protopapa, A. Preliminary Evaluation of Plasmix Compound from Plastics Packaging Waste for Reuse in Bituminous Pavements. Sustainability 2021, 13, 2258. [CrossRef]

22. Amrani, M.; Taha, Y.; El Haloui, Y.; Benzaazoua, M.; Hakkou, R. Sustainable Reuse of Coal Mine Waste: Experimental and Economic Assessments for Embankments and Pavement Layer Applications in Morocco. Minerals 2020, 10, 851. [CrossRef]

23. Piao, Z.; Mikhailenko, P.; Kakar, M.R.; Bueno, M.; Hellweg, S.; Poulikakos, L.D. Urban mining for asphalt pavements: A review. J. Clean. Prod. 2021, 280, 124916. [CrossRef]

24. Gautam, L.; Jain, J.K.; Kalla, P.; Choudhary, S. A review on the utilization of ceramic waste in sustainable construction products. Mater. Today Proc. 2020. [CrossRef]

25. Pasandín, A.R.; Pérez, I. Overview of bituminous mixtures made with recycled concrete aggregates. Constr. Build. Mater. 2015, 74, 151-161. [CrossRef]

26. Terrones-Saeta, J.M.; Suárez-Macías, J.; Iglesias-Godino, F.J.; Corpas-Iglesias, F.A. Development of High Resistance Hot Mix Asphalt with Electric Arc Furnace Slag, Ladle Furnace Slag, and Cellulose Fibers from the Papermaking Industry. Appl. Sci. 2021, 11, 399. [CrossRef]

27. Terrones-Saeta, J.M.; Suárez-Macías, J.; Iglesias-Godino, F.J.; Corpas-Iglesias, F.A. Development of Porous Asphalt with Bitumen Emulsion, Electric arc Furnace Slag and Cellulose Fibers for Medium Traffic Roads. Minerals 2020, 10, 872. [CrossRef] 
28. Terrones-Saeta, J.M.; Suárez-Macías, J.; Iglesias-Godino, F.J.; Corpas-Iglesias, F.A. Evaluation of the Use of Electric Arc Furnace Slag and Ladle Furnace Slag in Stone Mastic Asphalt Mixes with Discarded Cellulose Fibers from the Papermaking Industry. Metals 2020, 10, 1548. [CrossRef]

29. Saberian, M.; Li, J.; Boroujeni, M.; Law, D.; Li, C.Q. Application of demolition wastes mixed with crushed glass and crumb rubber in pavement base/subbase. Resour. Conserv. Recycl. 2020, 156, 104722. [CrossRef]

30. UNE-EN 1097-7:2009 Tests for Mechanical and Physical Properties of Aggregates-Part 3: Determination of Loose Bulk Density and Voids. Available online: https:/ / www.une.org/encuentra-tu-norma/busca-tu-norma/norma?c=N0042553 (accessed on 16 September 2020).

31. UNE-EN 1097-3:1999 Tests for Mechanical and Physical Properties of Aggregates-Part 3: Determination of Loose Bulk Density and Voids. Available online: https:/ / www.une.org/encuentra-tu-norma/busca-tu-norma/norma/?c=N0009465 (accessed on 16 September 2020).

32. UNE-EN ISO 17892-12:2019 Laboratory Testing of Soil-Part 12: Determination of Liquid and Plastic Limits. Available online: https:/ / www.une.org/encuentra-tu-norma/busca-tu-norma/norma?c=N0062183 (accessed on 22 March 2021).

33. UNE-EN 1097-2:2010 Tests for Mechanical and Physical Properties of Aggregates-Part 2: Methods for the Determination of Resistance to Fragmentation. Available online: https://www.une.org/encuentra-tu-norma/busca-tu-norma/norma/?c=N00460 26 (accessed on 16 September 2020).

34. UNE-EN 1367-1:2008 Tests for Thermal and Weathering Properties of Aggregates-Part 1: Determination of Resistance to Freezing and Thawing. Available online: https:/ / www.une.org/encuentra-tu-norma/busca-tu-norma/norma/?c=N0040756 (accessed on 16 September 2020).

35. UNE-EN 1097-8:2010 Tests for Mechanical and Physical Properties of Aggregates-Part 8: Determination of the Polished Stone Value. Available online: https://www.une.org/encuentra-tu-norma/busca-tu-norma/norma?c=N0044542 (accessed on 20 September 2020).

36. UNE-EN 1430:2009 Bitumen and Bituminous Binders-Determination of Particle Polarity of Bituminous Emulsions. Available online: https: / / www.une.org/encuentra-tu-norma/busca-tu-norma/norma/?c=N0044069 (accessed on 29 September 2020).

37. UNE-EN 13075-1:2017 Bitumen and Bituminous Binders-Determination of Breaking Behaviour-Part 1: Determination of Breaking Value of Cationic Bituminous Emulsions, Mineral Filler Method. Available online: https://www.une.org/encuentra-tu-norma/ busca-tu-norma/norma/?c=N0057840 (accessed on 29 September 2020).

38. UNE-EN 12846-1:2011 Bitumen and Bituminous Binders-Determination of Efflux Time by the Efflux Viscometer-Part 1: Bituminous Emulsions. Available online: https:/ / www.une.org/encuentra-tu-norma/busca-tu-norma/norma/?c=N0047377 (accessed on 29 September 2020).

39. UNE-EN 1431:2018 Bitumen and Bituminous Binders-Determination of Residual Binder and Oil Distillate from Bitumen Emulsions by Distillation. Available online: https: / / www.une.org/encuentra-tu-norma/busca-tu-norma/norma?c=N0060676 (accessed on 29 September 2020).

40. UNE-EN 12846:2003 Bitumen and Bituminous Binders. Determination of Efflux Time of Bitumen Emulsions by the Efflux Viscometer. Available online: https:/ / www.une.org/encuentra-tu-norma/busca-tu-norma/norma/?c=N0029984 (accessed on 29 September 2020).

41. UNE-EN 1429:2013 Bitumen and Bituminous Binders-Determination of Residue on Sieving of Bituminous Emulsions, and Determination of Storage Stability by Sieving. Available online: https: / /www.une.org/encuentra-tu-norma/busca-tu-norma/ norma? $=$ N0052189 (accessed on 29 September 2020).

42. UNE-EN 12847:2009 Bitumen and Bituminous Binders-Determination of Settling Tendency of Bituminous Emulsions. Available online: https: / /www.une.org/encuentra-tu-norma/busca-tu-norma/norma?c=N0044066 (accessed on 29 September 2020).

43. UNE-EN 13614:2011 Bitumen and Bituminous Binders-Determination of Adhesivity of Bituminous Emulsions by Water Immersion Test. Available online: https: / / www.une.org/encuentra-tu-norma/busca-tu-norma/norma?c=N0048094 (accessed on 29 September 2020).

44. UNE-EN 1426:2015 Bitumen and Bituminous Binders-Determination of Needle Penetration. Available online: https://www.une. org/encuentra-tu-norma/busca-tu-norma/norma/?c=N0055820 (accessed on 29 September 2020).

45. UNE-EN 1427:2015 Bitumen and Bituminous Binders-Determination of the Softening Point-Ring and Ball Method. Available online: https:/ / www.une.org/encuentra-tu-norma/busca-tu-norma/norma?c=N0055821 (accessed on 29 September 2020).

46. UNE-EN 13074-1:2019 Bitumen and Bituminous Binders-Recovery of Binder from Bituminous Emulsion or Cut-Back or Fluxed Bituminous Binders-Part 1: Recovery by Evaporation. Available online: https://www.une.org/encuentra-tu-norma/busca-tunorma/norma?c=N0062153 (accessed on 29 September 2020).

47. UNE-EN 13074-2:2011 Bitumen and Bituminous Binders-Recovery of Binder from Bituminous Emulsion or Cut-Back or Fluxed Bituminous Binders-Part 2: Stabilisation after Recovery by Evaporation. Available online: https://www.une.org/encuentra-tunorma/busca-tu-norma/norma/?c=N0047380 (accessed on 29 September 2020).

48. UNE-EN 12457-3:2003 Characterisation of Waste-Leaching-Compliance Test for Leaching of Granular Waste Materials and Sludges-Part 3: Two Stage Batch Test at a Liquid to Solid Ratio of $2 \mathrm{~L} / \mathrm{kg}$ and $8 \mathrm{~L} / \mathrm{kg}$ for Materials with High Solid Content and with Particle Size below $4 \mathrm{~mm}$ (without or with Size Reduction). Available online: https://www.une.org/encuentra-tu-norma/ busca-tu-norma/norma?c=N0029595 (accessed on 22 March 2021). 
49. BOE.es-BOE-A-1976-13091 Orden de 2 de Julio de 1976 por la que se Confiere Efecto Legal a la Publicación del Pliego de Prescripciones Técnicas Generales para obras de Carreteras y Puentes de la Dirección General de Carreteras y Caminos Vecinales (P. G. 3), Editado por el Servicio de Publicaciones del Ministerio. Available online: https://www.boe.es/buscar/doc.php?id= BOE-A-1976-13091 (accessed on 14 March 2021).

50. Soto, J.A.; Nebreda, J. Mezclas Abiertas en Frío. Available online: https://www.ateb.es/images/pdf/monografias/5._MEZCLAS_ ABIERTAS_EN_FRIO.pdf (accessed on 16 January 2021).

51. UNE-EN 12697-18:2018 Bituminous Mixtures-Test Methods-Part 18: Binder Drainage. Available online: https://www.une.org/ encuentra-tu-norma/busca-tu-norma / norma?c=N0061210 (accessed on 31 October 2020).

52. NLT-196/84 Envuelta y Resistencia al Desplazamiento por el Agua de las Emulsiones Bituminosas-Normativa de Carreteras. Available online: http:/ / normativadecarreteras.com/listing/nlt-19684-envuelta-resistencia-al-desplazamiento-agua-las-emulsionesbituminosas / (accessed on 29 September 2020).

53. UNE-EN 12697-30:2019 Bituminous Mixtures-Test Methods-Part 30: Specimen Preparation by Impact Compactor. Available online: https:/ / www.une.org/encuentra-tu-norma/busca-tu-norma/norma?c=N0062608 (accessed on 30 October 2020).

54. UNE-EN 12697-5:2020 Test Methods-Part 5: Determination of the Maximum Density. Available online: https://www.une.org/ encuentra-tu-norma/busca-tu-norma /norma?c=N0063145 (accessed on 29 September 2020).

55. UNE-EN 12697-6:2012 Bituminous Mixtures-Test Methods for Hot Mix Asphalt-Part 6: Determination of Bulk Density of Bituminous Specimens. Available online: https:/ / www.une.org/encuentra-tu-norma/busca-tu-norma/norma/?c=N0049868 (accessed on 29 September 2020).

56. UNE-EN 12697-8:2020 Bituminous Mixtures-Test Methods-Part 8: Determination of Void Characteristics of Bituminous Specimens. Available online: https:/ / www.une.org/encuentra-tu-norma/busca-tu-norma/norma/?c=N0063146 (accessed on 29 September 2020).

57. UNE-EN 12697-17:2018 Bituminous Mixtures-Test Methods-Part 17: Particle Loss of Porous Asphalt Specimens. Available online: https: / / www.une.org/encuentra-tu-norma/busca-tu-norma/norma?c=N0061209 (accessed on 22 March 2021).

58. NLT-362/92 Efecto del Agua Sobre la Cohesión de Mezclas Bituminosas de Granulometría Abierta, Mediante Ensayo Cántabro de Pérdida por Desgaste-Normativa de Carreteras. Available online: https:/ / normativadecarreteras.com/listing/nlt-36292-efectodel-agua-la-cohesion-mezclas-bituminosas-granulometria-abierta-mediante-ensayo-cantabro-perdida-desgaste/ (accessed on 22 March 2021).

59. UNE-EN 12697-34:2013 Bituminous Mixtures-Test Methods-Part 34: Marshall Test. Available online: https://www.une.org/ encuentra-tu-norma/busca-tu-norma/norma/?c=N0050744 (accessed on 22 March 2021).

60. Terrones-Saeta, J.M.; Suárez-Macías, J.; Iglesias-Godino, F.J.; Corpas-Iglesias, F.A. Study of the Incorporation of Biomass Bottom Ashes in Ceramic Materials for the Manufacture of Bricks and Evaluation of Their Leachates. Materials 2020, 13, 2099. [CrossRef]

61. Ficha Técnica Escorias de Acería de Horno de Arco Eléctrico. Available online: http:/ /www.cedexmateriales.es/upload/docs/ es_ESCORIASDEACERIADEHORNODEARCOELECTRICODIC2013.pdf (accessed on 30 March 2021). 